\title{
Isolation of $\alpha_{1}$-Protease Inhibitor from Human
}

\section{Normal and Malignant Ovarian Tissue}

\author{
A. Bagdasarian, J. Wheeler, G. J. Stewart, S. S. Ahmed, and R. W. Colman, \\ Specialized Center for Thrombosis Research, Temple University Health Sciences \\ Center; Departments of Medicine and Pathology, University of Pennsylvania \\ School of Medicine, Philadelphia, Pennsylvania 19140
}

\begin{abstract}
A B S T RAC T Proteolytic enzymes are associated with normal and neoplastic tissues. Therefore protease inhibitors might also be involved in the control of cell function. $\alpha_{1}$-protease antigen and antitryptic activity have been found in normal and neoplastic human ovarian homogenate. The inhibitor has been localized to ovarian stromal cells or tumor cells by immunoperoxidase staining. The protein was purified to apparent homogeneity as judged by alkaline gel and sodium dodecyl sulfate (SDS) gel electrophoresis. Immunochemical studies revealed antigenic similarity to plasma $\alpha_{1}$-protease inhibitor by double immunodiffusion and similar mobility on immunoelectrophoresis and two-dimensional electroimmunodiffusion. The molecular weight was similar to that described for plasma $\alpha_{1}$-protease inhibitor: 60,000 by gel filtration and 53,500 by SDS electrophoresis. Furthermore, the phenotypic pattern as determined by acid starch gel electrophoresis and immunoprecipitation was PiMM, which is the predominant genetic variant in normal plasma $\alpha_{1}$-protease inhibitor. An inhibitor was isolated and purified from an ovarian carcinoma that exhibited functional, immunochemical, and physical similarity to the normal ovarian $\alpha_{1}$-protease inhibitor. $\alpha_{1}$-protease inhibitor from normal and malignant ovaries competitively inhibited bovine pancreatic trypsin at incubation times of $5 \mathrm{~min}$ at $30^{\circ} \mathrm{C}$. Inhibition constant $\left(K_{\mathrm{i}}\right)$ values were calculated at 0.67 and 0.51 inhibitory units, respectively. The $\alpha_{1}$-protease inhibitor in malignant cells may be a factor in the control of proliferation in this tissue. Since ovulation is in part a proteolytic event, the $\alpha_{1}$-protease inhibitor in ovarian cells may play a role in the control of this specialized tissue. Persistance of this protein in malignant ovarian tissue may be a vestige of its differentiated origin.
\end{abstract}

Dr. Bagdasarian's current address is Hyland Laboratories, Therepeutic Division, Glendale, Calif.

Received for publication 16 July 1980 and in revised form 17 September 1980.

\section{INTRODUCTION}

$\alpha_{1}$-Protease inhibitor ( $\alpha_{1}$-antitrypsin) is a glycoprotein that probably functions as the major inhibitor of tissue proteases including trypsin (1), chymotrypsin (1), elastase (2), collagenase (3), and renin (4). The importance of $\alpha_{1}$-protease inhibitor in human disease is indicated by the observation that its deficiency is associated with pulmonary emphysema $(5,6)$ and liver disease $(7,8)$. Direct and indirect evidence suggests that the liver is the site of synthesis of the plasma $\alpha_{1}$ protease inhibitor (9-12). However, the action of this inhibitor is directed primarily toward tissue rather than plasma proteolytic enzymes, suggesting that it might also be synthesized in cells and tissue aside from the liver. The occurrence of $\alpha_{1}$-protease inhibitor in extrahepatic sites may be important, since certain protease inhibitors inhibit the growth of tumor cells $(13,14)$ or the process of transformation (15). Thus, the increased level of protease activity in malignant cells $(16,17)$ might be due to a deficiency of protease inhibitors in these cells. In addition, the role of proteolysis in such physiological events as ovulation (18), suggests that inhibitory function might exist for tissue $\alpha_{1}$-protease inhibitor, were it present.

In this study ovarian tissue was selected for detailed examination for three reasons. The ovary with its hormonally controlled cyclic proliferation and involution represents a tissue capable of high levels and diversified types of protein synthesis. Malignant and normal tissue can be obtained in reasonable amounts for protein isolation. A discrete physiological function, that of ovulation, is known to be associated with proteolytic activity involving trypsin-like enzymes (18). This study demonstrates that ovarian stromal cells contain $\alpha_{1}$-protease inhibitor and that the major trypsin inhibitory activity of ovarian tissue is due to this inhibitor. The $\alpha_{1}$-protease inhibitor has been purified and characterized from normal and malignant cells and this appears to be conserved in neoplastic cells. 
Finally, the occurrence of this inhibitor in the ovary invites future exploration of its role in ovulation.

\section{METHODS}

Ovary procurement. Three normal, one polycystic, and five malignant ovaries were obtained from nine patients during surgery. A representative portion was removed and fixed in Bouin's solution, dehydrated, and embedded in paraffin blocks. Sections from all nine were used for hematoxylin and eosin staining and for immunoperoxidase studies for $\alpha_{1}$-protease inhibitor (see below). Three ovaries were selected for in depth study of the $\alpha_{1}$-protease inhibitor. One was a normal postmenopausal ovary without follicles (B.L.), the second a polycystic ovary with multiple follicles (A.S.), and the third was a mucinous cystadenocarcinoma containing no follicles (G.B.). These were used for preparation of tissue homogenates for isolation of $\alpha_{1}$-protease inhibitors.

Immunocytochemical techniques. Immunoperoxidase reactions for $\alpha_{1}$-antitrypsin were tested on unstained, deparaffinized, and hydrated $6 \mu \mathrm{m}$ sections, by using commercially available reagents (see "Antisera") and brief rinses with $0.1 \mathrm{M}$ sodium phosphate buffer $\mathrm{pH} 7.4$ containing $0.15 \mathrm{M} \mathrm{NaCl}$ (PBS) ${ }^{1}$ between steps, in a three-layered immunoenzyme bridge technique with unlabeled antibody and soluble peroxidase-antiperoxidase complex (19). The technique involved slide incubation in a moist chamber, and the following timed application sequence: (a) 1:40 rabbit anti-human $\alpha_{1-}$ antitrypsin, prepared by diluting the antiserum 1:20 with PBS, then adding an equal volume of undiluted normal goat serum, $30 \mathrm{~min}$; (b) undiluted normal goat serum, $15 \mathrm{~min}$; (c) 1:50 goat anti-rabbit IgG, using a 1:25 dilution with PBS, then addition of an equal volume of 1:10 normal goat serum diluted with PBS, $30 \mathrm{~min}$; (d) 1:50 peroxidase-antiperoxidase complex, diluted 1:25 with PBS, then 1:10 normal goat serum, $30 \mathrm{~min}$; (e) 3,3'-diaminobenzidine/hydrogen peroxide solution, prepared immediately before use, by dissolving $5 \mathrm{mg}$ of diaminobenzidine in $10 \mathrm{ml}$ of $0.05 \mathrm{M}$ Tris $\mathrm{HCl}$ buffer, $\mathrm{pH} \mathrm{7.2,} \mathrm{then}$ adding four to five drops of $3 \% \mathrm{H}_{2} \mathrm{O}_{2}, 5-10 \mathrm{~min}$; followed by counterstaining, dehydration, permanent mounting, and examination by light microscopy $(20)$.

The specificity of the primary antiserum was tested before use by double diffusion (21). For control, primary antiserum was replaced with normal rabbit serum, PBS, or absorbed primary antiserum.

Chemicals. Acrylamide, $N, N^{\prime}$-methylene-bis-acrylamide, $N, N, N^{\prime}, N^{\prime}$-tetramethylene diamine were obtained from BioRad Laboratories, Richmond, Calif. Coomassie blue was obtained from Ames Co., Div. of Miles Laboratories, Elkhart, Ind. Ammonium persulfate was purchased from Fisher Scientific Co., Pittsburgh, Pa. Agarose from Litex Co., Copenhagen, Denmark. Plates containing $1 \%$ agarose for double diffusion were obtained from Hyland Diagnostics Div. Travenol Laboratories, Costa Mesa, Calif. Hexadimethrene bromide (polybrene) was obtained from Abbott Laboratories, North Chicago, Ill. Dithiothreitol, dextran blue and 3,3'-diaminobenzidine were from Sigma Chemical Co., St. Louis, Mo. Sodium dodecyl sulfate was obtained from Schwartz/Mann Div., Becton, Dickinson \& Co., Orangeburg, N. Y. QAE-Sephadex, Sephadex G-200, Sepharose-4B, concanavalin A (Con A)-Sepharose and Blue Dextran 2000 were obtained from Pharmacia Fine Chemicals, Div. Pharmacia Inc., Piscataway, N. J. Preswollen DEAEcellulose was purchased from Whatman Inc., Clifton, N. J. All other chemicals were reagent grade.

${ }^{1}$ Abbreviation used in this paper: PBS, $0.1 \mathrm{M}$ phosphatebuffered saline (pH 2.4) containing $0.15 \mathrm{M} \mathrm{NaCl}$.
Molecular weight standards. For the calibration of gel filtration columns the following standards were obtained from Sigman Chemical Co.: twice crystallized bovine serum albumin, $\alpha$-chymotrypsinogen (bovine pancreas, type II, six times crystallized), ovalbumin (crystallized and salt free), and human $\gamma$-globulin.

Substrates. Benzoyl-L-phenylalanyl-L-valyl-L-arginyl-pnitroanilide (Bz-Phe-Val-Arg- $p$ NA) was purchased from Kabi Peptide Research Molndal, Sweden. Bz-Phe-Val-Arg- $p$ NA was dissolved in distilled water, either by stirring for $1 \mathrm{~h}$ or by sonication for four periods of $14 \mathrm{~s}$ each to yield a $1 \mathrm{mM}$ solution. H, D-phenylalanyl-L-valyl-L-arginyl- $p$-nitroanilide (H-D-ValLeu-Lys- $p$ NA) was purchased from Ortho Diagnostics, Rari$\tan$, N. J., and $3 \mathrm{mM}$ solution was prepared in distilled water. H-D-Glu-Gly-Arg- $p$ NA was a gift from Kabi Peptide Research Molndal, Sweden. Para-nitrophenyl-p-guanidinobenzoate $\mathrm{HCl}$ was purchased from Vega Fox Biochemicals, Div. Newbery Energy Tucson, Ariz. $\alpha$-Casein was obtained from Fisher Scientific Co. Benzamidine hydrochloride hydrate was purchased from Aldrich Chemical Co., Inc., Milwaukee, Wisc.

Enzymes. Bovine pancreatic trypsin (crystallized three times) treated with tosylphenylalanylchloromethyl ketone to render it free of chymotryptic activity was obtained from Worthington Biochemical Corp., Freehold, N. J. Plasminogen was prepared by affinity chromatography $(22)$ or was purchased from Kabi, Stockholm, Sweden. Both preparations of plasminogen gave similar results. Varidase (Lederle Laboratories, Div. American Cyanamid Co., Pearl River, N. Y.) was the source of streptokinase. Human plasma kallikrein was prepared in our laboratory by alcohol and salt fractionation and ion exchange chromatography and was futher purified by gel filtration (23). Urokinase was obtained from CalbiochemBehring Corp., American Hoechst Corp., San Diego, Calif.

Antisera. Antibodies prepared in rabbits against human plasma proteins, anti- $\alpha_{1}$-antitrypsin, anti-inter- $\alpha$-trypsin inhibitor, anti- $\alpha_{2}$-macroglobulin, anti-CI inhibitor, anti-thrombin III, anti-transferrin, and anti-haptoglobin were obtained from Behring Diagnostics, Somerville, N. J. Anti- $\alpha_{2}$ plasmin inhibitor was a gift from Dr. Aoki of Jichi Medical School, Japan. Peroxidase conjugated to anti-rabbit gamma globulin and goat anti-rabbit IgG were purchased from N. L. Cappel Laboratories, Cochranville, $\mathrm{Pa}$.

Column chromatography and gel filtration. QAE and G200 Sephadex and DEAE-cellulose were equilibrated with the starting buffer according to the directions of the manufacturer, and were packed into columns by gravity. A standard curve was constructed to estimate molecular weights by gel filtration. The following proteins were used: human $\gamma$-globulin, bovine serum albumin, ovalbumin, and $\alpha$-chymotrypsinogen. Sephadex G-200 filtration was carried out using a downward flow column $(1.6 \times 86.5 \mathrm{~cm})$ at a constant operating pressure of $40 \mathrm{~cm}$. Samples of up to $2 \%$ of the column volume were applied. The flow rate was $8 \mathrm{ml} / \mathrm{h}$.

Affinity chromatography. To remove albumin from purified inhibitor, a Con A-Sepharose column was used. A small column $(2 \mathrm{ml}$ vol) was packed and equilibrated with $0.01 \mathrm{M}$ acetate buffer at pH 6.5 containing $0.2 \mathrm{M} \mathrm{NaCl}, 1 \mathrm{mM}$ of each $\mathrm{CaCl}_{2}$ and $\mathrm{MnCl}_{2}$. Inhibitor samples containing $<10 \mathrm{mg}$ total protein were passed through the resin at $4^{\circ} \mathrm{C}$. After the removal of the unabsorbed proteins by the starting buffer, the inhibitor was eluted from the Con A-Sepharose with a 0.1-M solution of $\alpha$-methyl-D-glucoside in the $0.05 \mathrm{M}$ Tris buffer. 1-ml fractions were collected and assayed for trypsin inhibition. For functional studies, fractions containing the inhibitor were pooled and stabilized with bovine serum albumin $100 \mu \mathrm{g} / \mathrm{ml}$ before concentration. The recovery of inhibitor is generally $\sim 75 \%$ based on the total trypsin inhibitory capacity of the material applied to the column. 
Gel electrophoresis. Analytical polyacrylamide disc gel electrophoresis was performed according to Davis (24). Samples in $4 \%$ sucrose were applied to $7 \%$ polyacrylamide gels, and electrophoresis was carried out for $2 \mathrm{~h}$ at $4^{\circ} \mathrm{C}, 2.5 \mathrm{~mA}$ per gel. To locate protein bands, gels were stained for $3 \mathrm{~h}$ with $0.1 \%$ Coomassie blue. Polyacrylamide gel electrophoresis in sodium dodecyl sulfate was performed according to Weber and Osborn (25). A standard curve for the calibration of the molecular weights was constructed using the molecular weight markers for sodium dodecyl sulfate gel electrophoresis, obtained from BDH Chemicals Ltd., Poole, England.

Tissue homogenization and subcellular fractionation. Tissues were obtained from surgery and carefully washed free of any adhering blood clots and frozen immediately if not processed right away. All operations were carried out at $4^{\circ} \mathrm{C}$. Each $10 \mathrm{~g}$ of fresh or frozen tissue was cut in small pieces $(\sim 3 \mathrm{~mm}$ thick) and rinsed with $150 \mathrm{ml}$ ice-cold solution of 0.25 $\mathrm{M}$ sucrose in $0.01 \mathrm{M}$ Tris-Cl buffer $\mathrm{pH} 7.4$ containing $1 \mathrm{mM}$ EDTA, azide, benzamidine, and $50 \mu \mathrm{g}$ per $\mathrm{ml}$ hexadimethrine. Rinsing was repeated three times for $30 \mathrm{~min}$. Tissue slices were then placed on a stainless steel sieve ( 40 mesh) and rinsed once more with $50 \mathrm{ml}$ of the above buffer. The rinsed tissue was then pressed through the sieve and taken up in the same buffer $(6 \mathrm{ml} / \mathrm{g}$ tissue $)$ and homogenized in small aliquots using an all-glass loose-fitting homogenizer of Dounce type. The final homogenate was taken up in a total of $10 \mathrm{ml} \mathrm{buffer} / \mathrm{g}$ tissue. Subcellular fractions were then prepared by the general method of differential centrifugation (26). Lysosomes were further purified from the light mitochondria by sucrose density gradient centrifugation (27). To solubilize lysosomal contents, deoxycholate solution at final concentration of $0.5 \%$ was added to the suspended lysosomes in $0.0035 \mathrm{M}$ phosphate buffer, containing $0.06 \mathrm{M} \mathrm{NaCl}, \mathrm{pH} 8.0$, and incubated at $0^{\circ} \mathrm{C}$ for 30 min before centrifugation for $30 \mathrm{~min}$ at $12,000 \mathrm{~g}$ to obtain clear supernate.

Ammonium sulfate precipitation. Saturated ammonium sulfate solution adjusted to $\mathrm{pH} 7.0$ by the addition of $1 \mathrm{M}$ $\mathrm{NaOH}$ solution, was added to the $100,000 \mathrm{~g}$ supernate from rinsed homogenized tissue or solubilized lysosomal contents at $0^{\circ} \mathrm{C}$ with constant stirring. After $45 \mathrm{~min}$ the precipitate was collected by centrifugation at $3,000 \mathrm{~g}$ at $4^{\circ} \mathrm{C}$ for $30 \mathrm{~min}$ and redissolved in the $0.01 \mathrm{M}$ Tris- $\mathrm{HCl}$ buffer, $\mathrm{pH}$ 8.0. Samples were dialyzed against $0.05 \mathrm{M}$ Tris buffer, $\mathrm{pH} 8.0$, overnight.

Immunological analysis. Double-immunodiffusion was performed by the method of Ouchterlony (21) using $1 \%$ agarose plates. Radial immunodiffusion was performed by a minor modification of the method of Mancini et al. (28) with a final concentration of $1 \%$ agarose in barbital buffer, $\mathrm{pH} 7.6,1: 36$ dilution of antiserum, and $0.01 \%$ merthiolate. Immunoelectrophoresis was performed by the method of Scheidigger (29), using $1 \%$ agarose plates. Crossed immunoelectrophoresis was carried out according to Laurell (30) with minor modifications. $\alpha$-protease inhibitor phenotyping was carried out according to Fagerhol and Laurell (31).

Preparation of immobilized trypsin. Sepharose-4B was activated by cyanogen bromide and coupled to bovine trypsin by the method of Cuatrecases (32) as previously described (33). Trypsin ( $100 \mathrm{mg}$ ) in $25 \mathrm{ml}$ of $0.1 \mathrm{M}$ sodium bicarbonate, pH 8.9, was added to the activated agarose slurry containing $40 \mathrm{ml}$ resin and $25 \mathrm{ml}$ of the above buffer. The concentration of active trypsin in solution or bound to agarose was determined by the active site titration method of Chase and Shaw (34). Approximately $1 \mathrm{mg}$ trypsin was linked to each milliliter of resin.

Inhibition of trypsin amidase activity. Inhibition by cell components was determined by measuring the degree of hydrolysis using a tripeptide $p$-nitroanilide substrate. Up to 0.30 $\mathrm{ml}$ of sample from different stages of purification was mixed with $0.05 \mathrm{M}$ Tris imidazole buffer, $\mathrm{pH} 8.1$, containing $0.1 \mathrm{M}$
$\mathrm{NaCl}$ and $0.5 \mathrm{mg} / \mathrm{ml}$ bovine serum albumin (in a total volume of $0.9 \mathrm{ml})$, and $0.01 \mathrm{ml}$ of trypsin $(0.3 \mu \mathrm{g})$. The mixture was incubated at $30^{\circ} \mathrm{C}$ for 5 min unless otherwise stated. At the end of the incubation period, $0.1 \mathrm{ml}$ of $1 \mathrm{mM}$ substrate Bz-Pro-ValArg- $p$ NA was added and incubated for $2 \mathrm{~min}$. The reaction was stopped by the addition of $0.1 \mathrm{ml}$ glacial acetic acid and the color formed measured at $405 \mathrm{~nm}$ with a Gilford 240 spectrophotometer (Gilford Instrument Laboratories, Inc., Oberlin, Ohio). The blanks did not contain trypsin and the control contained buffer instead of sample.

Inhibition of trypsin proteolytic activity. A mixture of up to $0.3 \mathrm{ml} 0.1 \mathrm{M}$ phosphate buffer at $\mathrm{pH} 7.65,0.01 \mathrm{ml}$ trypsin $(0.3 \mu \mathrm{g})$, and bovine serum albumin at a final concentration of $0.5 \mathrm{mg} / \mathrm{ml}$ was incubated for $4 \mathrm{~min}$ at $30^{\circ} \mathrm{C}$. The degree of hydrolysis of casein and the extent of the inhibition were determined according to the method of Alkjaersig et al. (35).

Inhibitor units. Hydrolysis of Bz-Pro-Val-Arg-pNA and $\mathrm{H}_{-}$ D-Val-Leu-Lys- $p$ NA was linear for at least 3 min under the experimental conditions. In the trypsin or plasmin amidase assays, when the remaining enzymes' activity was plotted on a semilog graph against the concentration of the inhibitor, a linear relationship was obtained. Therefore, we arbitrarily chose $1 \mathrm{U}$ of inhibitor to be equal to that amount that could inhibit $50 \%$ of trypsin $(0.30 \mu \mathrm{g})$ or plasmin ( 0.05 casein units) activity.

Inhibition of plasmin amidase activity. The tripeptide substrate, H-D-Val-Leu-Lys- $p$ NA was used. Up to $0.3 \mathrm{ml}$ of inhibitor source was mixed with $0.05 \mathrm{M}$ Tris-Cl buffer at $\mathrm{pH}$ 7.4 , containing $1 \mathrm{mg} / \mathrm{ml}$ bovine serum albumin in a total volume of $0.9 \mathrm{ml}$; and $0.01 \mathrm{ml}$ of plasmin ( 0.05 casein units). After incubation of the mixture for $5 \mathrm{~min}, 0.1 \mathrm{ml}$ of the substrate $(3 \mathrm{mM})$ was added and further incubated for $3 \mathrm{~min}$. The reaction was stopped by the addition of $0.1 \mathrm{ml}$ of $50 \%$ glacial acetic acid and the color formed measured at $405 \mathrm{~nm}$. The blanks did not contain plasmin and the controls contained buffer instead of sample.

Affinity chromatography of trypsin inhibitors. To selectively isolate trypsin inhibitors, soluble fraction or lysosomal content from various tissues were exposed to trypsin-sepharose columns (36), equilibrated with $0.05 \mathrm{M}$ Tris-Cl buffer, pH 7.4 containing $0.13 \mathrm{M} \mathrm{NaCl}$, at $4^{\circ} \mathrm{C}$. The resin was further washed with $0.3 \mathrm{M} \mathrm{NaCl}, 0.02 \mathrm{M} \mathrm{CaCl}_{2}$ solution (twice the column volume) and the trypsin inhibitors were eluted with $0.02 \mathrm{M} \mathrm{HCl}$ containing $0.3 \mathrm{M} \mathrm{NaCl}, 0.02 \mathrm{M} \mathrm{CaCl}_{2}$.

Determination of protein concentration. Fractions obtained from chromatography were examined for their absorption at $280 \mathrm{~nm}$. For a more sensitive estimation of the protein concentration, the micro-Folin-Ciocalteu method was used. The specific activities of inhibitors were expressed as units per milligram protein.

Concentration of protein samples. Fractions containing various inhibitory activities were pooled and concentrated in an Amicon ultrafiltration device (Amicon Corp., Scientific Sys. Div., Lexington, Mass.) using a YM-10 membrane.

\section{RESULTS}

Demonstration of $\alpha_{1}$-protease inhibitor in ovaries by the indirect peroxidase reaction. The presence of $\alpha_{1}$ protease inhibitor antigen in formalin-fixed paraffin sections of nine freshly removed ovaries was shown by the use of specific $\alpha_{1}$-protease inhibitor antibody and a binding antibody conjugated to peroxidase. In normal ovaries the reaction product (representing antigen) was intense in the germinal epithelium covering the 
A

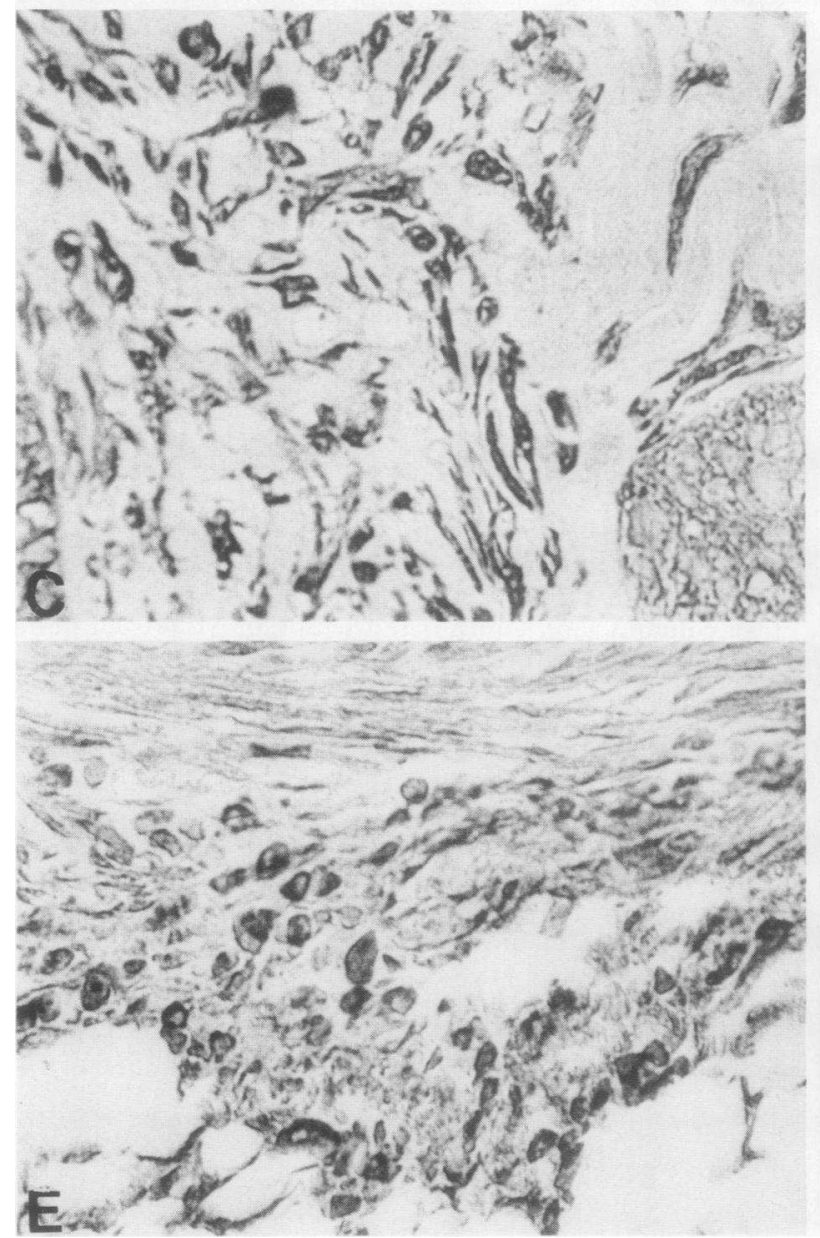

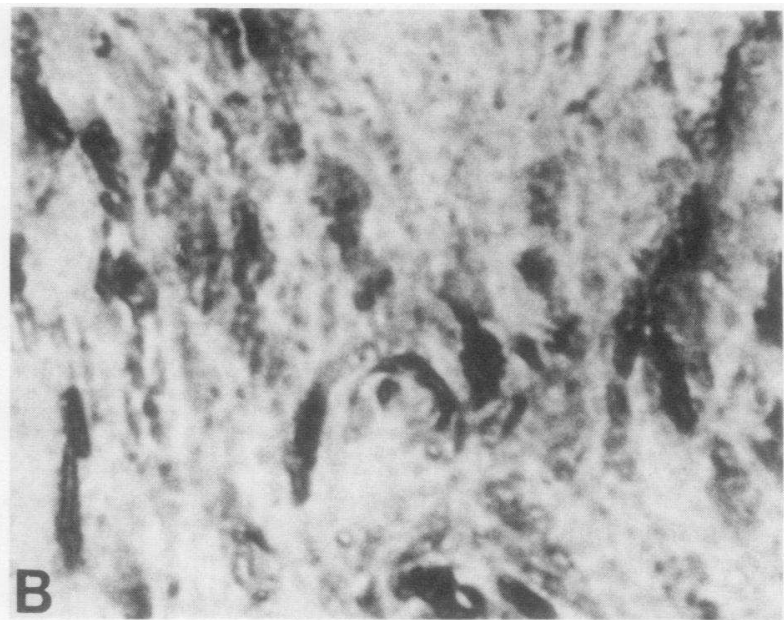
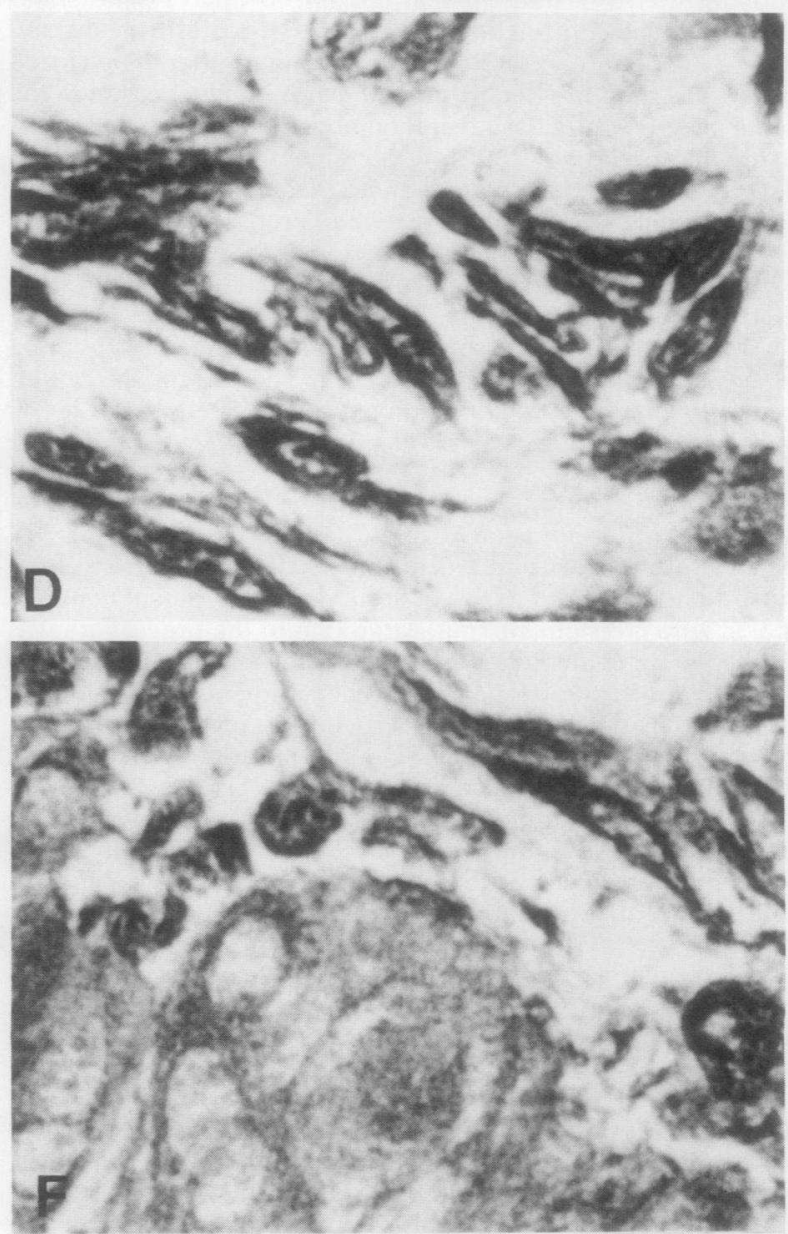

FIGURE 1 Immunocytochemical localization of $\alpha_{1}$-antitrypsin in ovaries by indirect peroxidaseantiperoxidase procedure. All frames are light micrographs. Frame A establishes the specificity of the antibody and peroxidase reaction by showing the absence of reaction product when normal rabbit serum was substituted for specific antibody in the primary step. This was used as a control for all ovaries examined. Note the absence of reaction product from stromal cells whereas faint reaction product is present in vessels indicating the presence of endogenous peroxidase in the blood cells, $\times 400$. Frames B-F show the distribution of dense (dark) reaction product which corresponds to distribution of $\alpha_{1}$-antitrypsin antigen when specific $\alpha_{1}$-antitrypsin antibody was used in 
ovary and specially in the stromal cells of the cortex (Fig. 1). In contrast, the follicular cells and the interstitial space were essentially free of reaction product. Samples that were not exposed to the specific antibody for $\alpha_{1}$-protease inhibitor before exposure to the peroxidase conjugate and substrate showed no reaction product in ovarian cells or interstitial space, but the cellfilled blood vessels developed a faint reaction product with the substrate alone, indicating the presence of endogenous peroxidase in the blood cells. This has been demonstrated for the granules of granulocytes as well as for hemeproteins (20). In the malignant tissue the reaction product was more dense but very irregularly distributed in the stroma and confined to only some of the stromal cells but most of the tumor cells. All corpora lutea were completely devoid of reaction product or were barely visible. Nine ovaries, (three normal, one polycystic, and five malignant) from nine patients, all showed the same pattern of distribution of $\alpha_{1}$-protease inhibitor antigen.

Identification of $\alpha_{1}$-protease inhibitor in ovarian homogenate subfractions by immunochemical characteristics and inhibitor activity. Subcellular fractions of a normal ovary (B.L.), a polycystic ovary (A.S.), and an adenocarcinoma of ovary (G.B.) were prepared as described in Methods. In the nonmalignant ovary (A.S.) (Fig. 2a) the antigen detected, $\alpha_{1}$-protease inhibitor, was found in the homogenate (not shown) and soluble fraction (well 3). The Triton-solubilized membrane fraction showed a faint line (well 4). Both cell fractions demonstrated complete identity with plasma $\alpha_{1}$-protease inhibitor (wells 2,5). The concentration of $\alpha_{1}$ protease inhibitor in the soluble fractions of normal ovary (B.L.) and polycystic ovary (A.S.) were 30 and 9 $\mu \mathrm{g} / \mathrm{mg}$ protein, respectively, using radial immunodiffusion.

The ovarian carcinoma (G.B.) (Fig. 2b) soluble fraction (well 1) showed complete identity with plasma $\alpha_{1}$ protease inhibitor (well 2). The membrane fraction solubilized in Triton (well 3) also showed a line of identity with plasma $\alpha_{1}$-protease inhibitor (wells 2 and 4). Solubilization of the membrane in deoxycholate (well 5) completely interfered with the antigen antibody reaction. The soluble fraction from normal ovary tested by radial immunodiffusion showed small amounts of $\alpha_{1}$-antichymotrypsin $(5.9 \mu \mathrm{g} / \mathrm{mg}$ protein) and inter$\alpha$-antitrypsin (3 $\mu \mathrm{g} / \mathrm{mg}$ protein). Soluble and lysosomal fractions from carcinoma (G.B.) also showed the presence of small amounts of inter- $\alpha$-antitrypsin. The concentration of $\alpha_{1}$-protease inhibitor in the soluble fraction was assayed at $18 \mu \mathrm{g} / \mathrm{mg}$ protein using radial immunodiffusion.

To study the electrophoretic mobilities of $\alpha_{1}$-protease inhibitor from various sources, soluble fractions from normal ovary (A.S.) and ovarian carcinoma (G.B.) were compared to plasma $\alpha_{1}$-protease inhibitor by immunoelectrophoresis (Fig. 3). A similar mobility to plasma $\alpha_{1}$-protease inhibitor (B) was found for neoplastic (A) and normal (C) ovary when monospecific antiserum against $\alpha_{1}$-protease inhibitor I and II were used.

Functional localization of trypsin inhibitors. Subcellular fractions from normal (A.S.) and malignant (G.B) ovary were tested for trypsin inhibition using peptide substrate (Bz-Phe-Val-Arg-pNA). Trypsin inhibitory activity was present mainly in the soluble fraction (80\% of the total activity). Lysosomal and membrane fractions contained 11.2 and $8.4 \%$ of the total activity. About $75 \%$ of the antitrypsin activity in the soluble fractions was located in the $50-80 \%$ saturation precipitate of ammonium sulfate and the remaining $25 \%$ of the activity was in the $25-50 \%$ saturation fraction. The homogenate and subcellular fractions of normal and malignant ovaries (80-100 $\mu \mathrm{g}$ total protein) were tested for urokinase inhibition. No inhibitory activity was found. The soluble fractions of normal and malignant ovaries revealed low levels of antiplasmin activity using H-D-Val-Leu-Lys-pNA. This activity is precipitated by ammonium sulfate at $25-50 \%$ saturation.

Purification of $\alpha_{1}$-protease inhibitor. Since the major portion of cellular $\alpha_{1}$-protease inhibitor was found in the soluble fraction, this fraction was used as the source for the $\alpha_{1}$-protease inhibitor purification. The normal ovary obtained from B.L. was fractionated as described in Methods. The $\alpha_{1}$-protease inhibitor was localized in soluble and membrane fractions, while the antitrypsin activity was also present in the lysosomes. Similar results were obtained for the tissues of A.S. and G.B. Results of the QAE-Sephadex chromatography on the normal ovary soluble fraction are presented in Fig.

the primary step in staining both normal and neoplastic ovaries. Frame B shows part of a normal ovarian cortex containing intense reaction product in epithelial and stromal cells, $\times 400$. Frame $C$ shows an ovary with carcinoma with no reaction product in the typical tubular structures lined by clear and "hobnail" cells, whereas several cells in the stromal cytoplasm showed positive $\alpha_{1}$-antitrypsin reaction, $\times 400$. Frame $D$ shows at higher magnification serial section of the ovarian carcinoma shown in Frame $C$. Antigen is present in many stromal cells, $\times 500$. Frame $E$ shows an ovary with carcinoma with numerous cytoplasmic globules in necrotic region. The amount of stored $\alpha_{1}$ antitrypsin in the tumor globules as revealed by the peroxidase-antiperoxidase technique is quite irregular, $\times 400$. Frame $F$ shows an ovary with carcinoma with many tumor cells containing $\alpha_{1}$-antitrypsin $\times 450$. 


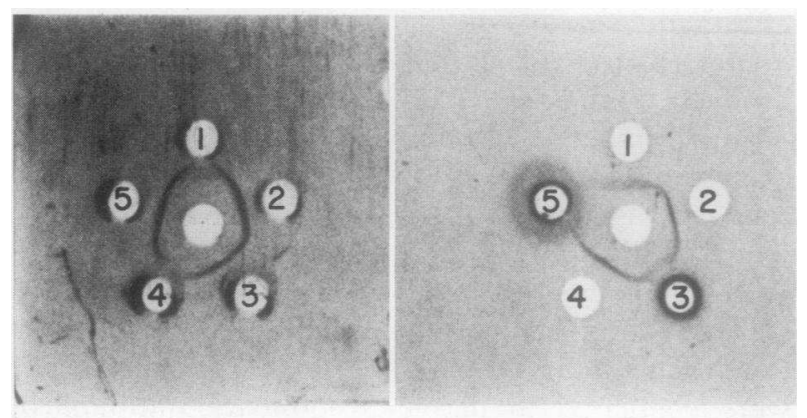

Figure 2 Double immunodiffusion of soluble and membrane fractions of normal and malignant ovaries. Plate a represents normal ovary samples: well $1,10 \mu$ l soluble fraction; wells 2 and $5,8 \mu$ l of 1:20 diluted sample of pooled normal plasma. Well 3 contains $20 \mu \mathrm{l}$ of soluble fraction, and well 4 $15 \mu \mathrm{l}$ of the membrane solubilized in Triton X-100. Plate b represents ovarian carcinoma: well $120 \mu \lambda$ of soluble fraction; wells 2 and $4,8 \mu$ of 1:20 diluted normal pooled plasma; well $3,20 \mu \mathrm{l}$ of membrane solubilized in Triton X-100, well 5, $20 \mu \mathrm{l}$ of membrane solubilized with deoxycholate. Center wells contain $7 \mu$ l of $\alpha_{1}$-protease inhibitor antiserum.

4. A single trypsin inhibitory peak as measured against the amide substrate Bz-Phe-Val-Arg- $p$ NA was eluted following the salt gradient, coincident with the $\alpha_{1}$-protease inhibitor antigen peak. Fractions indicated by the bar, containing the inhibitory activity and the $\alpha_{1}$-protease inhibitor antigen were pooled, concentrated, and gel filtered through a Sepharose-4B column (Fig. 5). A single peak of trypsin inhibitor activity that also demon- strated $\alpha_{1}$-protease inhibitor antigen (not shown) was located in a region corresponding to $\sim 60,000 \mathrm{~mol}$ wt. When fractions were tested for human plasmin inhibition using H-D-Val-Leu-Lys- $p$ NA peptide substrate, a small but distinct inhibitory activity was found under the antitrypsin peak. Alkaline disc gel analysis of the Sepharose-4B peak revealed several contaminating proteins including one with similar mobility to $\alpha_{1}$ glycoprotein. Therefore, this material was further purified by chromatography on DE-52 cellulose at $\mathrm{pH} 6.5$ (37). Results of the chromatography are summarized in Fig. 6. After removal of the unadsorbed proteins, the antitrypsin activity was eluted by applying a linear salt gradient (arrow) up to $0.2 \mathrm{M} \mathrm{NaCl}$. Fractions containing the antitrypsin activity were pooled, concentrated, and dialyzed against $0.01 \mathrm{M}$ Na-acetate buffer at $\mathrm{pH} 6.5$ containig $0.2 \mathrm{M} \mathrm{NaCl}, 1 \mathrm{mM} \mathrm{CaCl}_{2}$, and $1 \mathrm{mM} \mathrm{MgCl}_{2}$. To remove the major contaminant albumin, the sample was passed through Con A-Sepharose equilibrated with the above acetate buffer (Fig. 7). After complete removal of the unadsorbed proteins by the starting buffer, the $\alpha_{1}$-protease inhibitor was eluted by $0.1 \mathrm{M} \alpha$-Dmethyl-glucoside in a single symmetrical peak corresponding to a discrete protein peak. Similar procedures were applied for the purification of $\alpha_{1}$-protease inhibitor from the ovarian carcinoma. No major differences were noted in the chromatographic patterns compared to normal ovary.

The entire purification is summarized in Table I for both normal and malignant ovaries. On the basic of trypsin inhibitory activity an overall purification of 16 -

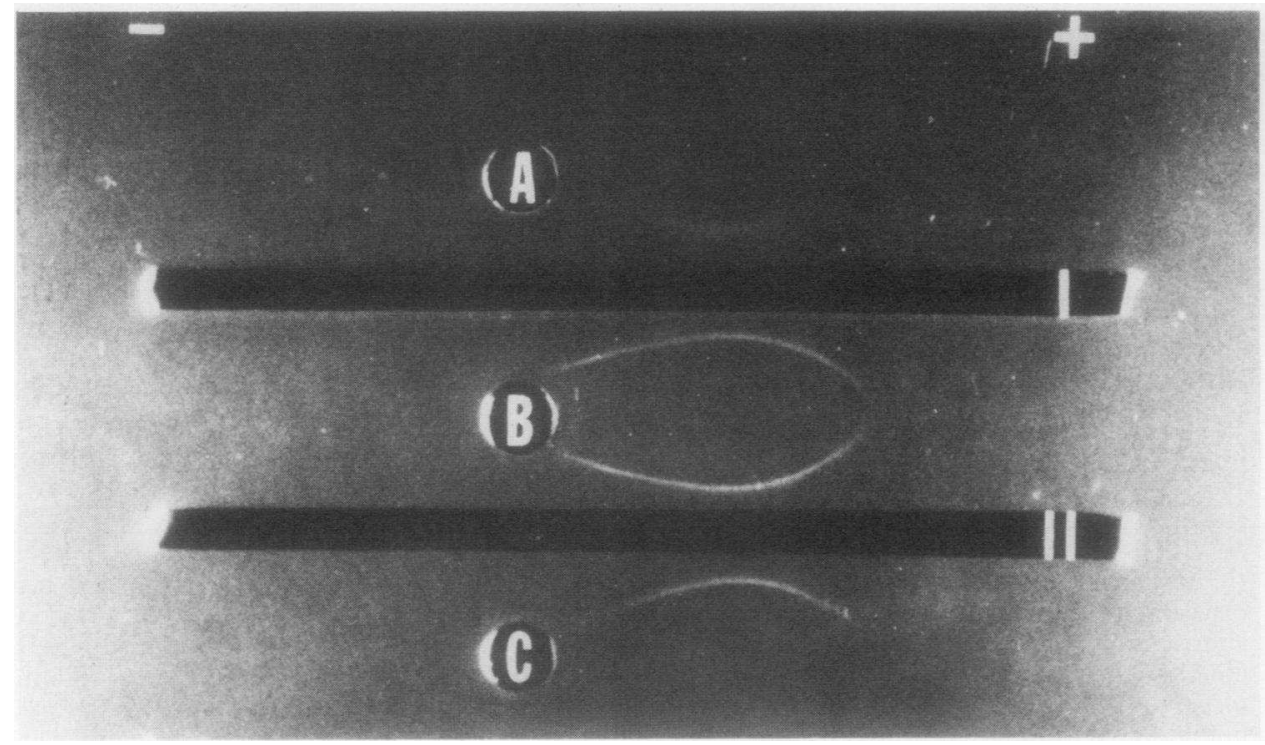

FIGURE 3 Immunoelectrophoresis of soluble fraction from normal and malignant ovaries. Wells contain the following samples: A, soluble fraction from ovarian carcinoma; B, diluted normal plasma; C, soluble fraction from normal ovary. In each case samples contained $\sim 50 \mu \mathrm{g}$ of total protein. Troughs I and II contained $60 \mu \mathrm{l}$ of $\alpha_{1}$-protease inhibitor antiserum. 


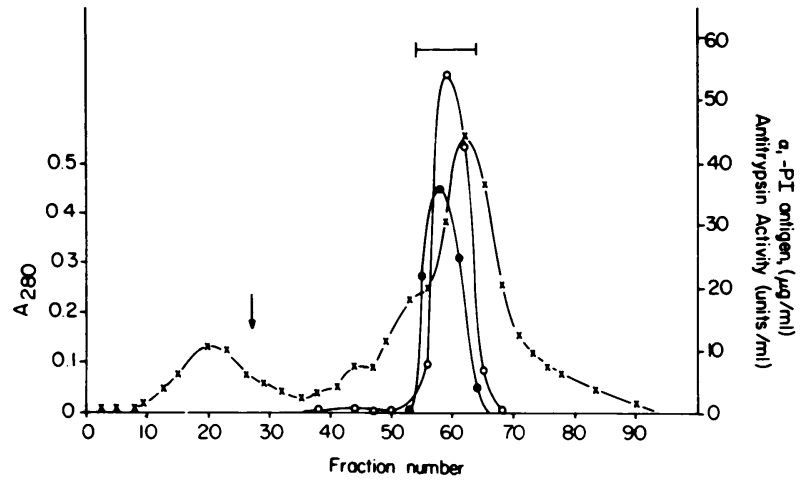

FIGURE 4 QAE-Sephadex chromatography of the normal ovary soluble fraction. A total of $60 \mathrm{mg}$ protein was applied onto a $1.6 \times 15-\mathrm{cm}$ column equilibrated with $0.0035 \mathrm{M}$ phosphate buffer containing $0.06 \mathrm{M} \mathrm{NaCl}$ at $\mathrm{pH}$ 8.0. As indicated by the arrow a gradient consisting of $150 \mathrm{ml}$ of starting buffer in the mixing chamber and $150 \mathrm{ml}$ of the same buffer containing $0.7 \mathrm{M} \mathrm{NaCl}$ in the reservoir was started. $3.3 \mathrm{ml}$ fractions were collected. $\times$ indicate $A_{280} ; \bigcirc$ antitrypsin activity; $\boldsymbol{\alpha}_{1}$ protease inhibitor antigen.

and 20-fold were obtained from normal and malignant ovaries, respectively. If one calculates the purification on the basis of $\alpha_{1}$-protease inhibitor antigen higher values of 30- and 44-fold were obtained. This apparent discrepancy is because of the inclusion of tryptic inhibitory activity due to other inhibitors distinct from $\alpha_{1}$ protease inhibitor in the starting soluble fraction. The yield for $\alpha_{1}$-protease inhibitor from both normal and malignant ovary, based on the antigen data is $\sim 20 \%$.

To demonstrate the homogeneity of the preparation, three criteria were chosen. An alkaline disc gel electrophoresis of highly purified preparation of $\alpha_{1}$-protease inhibitor (Fig. 8) obtained from normal and malignant ovaries revealed a single major protein band. The pro-

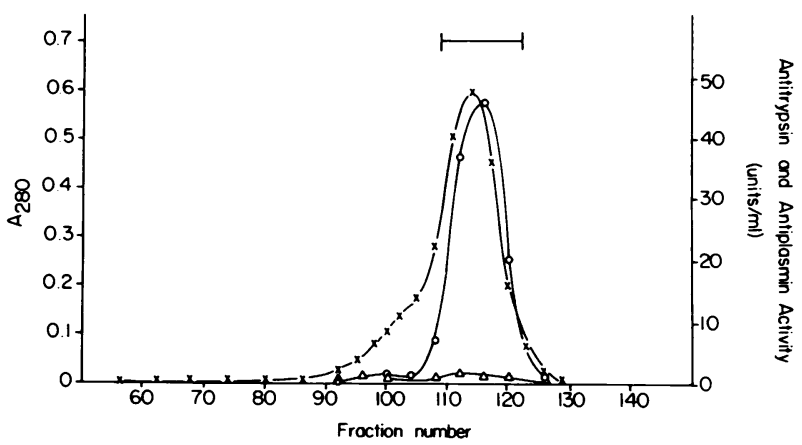

Figure 5 Sepharose-4B gel filtration. The pooled and concentrated fractions 56-63 $(|-|$, Fig. 3) from QAESephadex (14 mg total protein) were gel filtered through a $1.6 \times 86.5 \mathrm{~cm}$ column equilibrated with $0.01 \mathrm{M}$ Tris-Cl containing $0.13 \mathrm{M} \mathrm{NaCl}$ at $\mathrm{pH} 7.4$. Fractions of $1.3 \mathrm{ml}$ were collected. Symbols same as Fig. 4 but in addition $\Delta$ represent antiplasma activity.

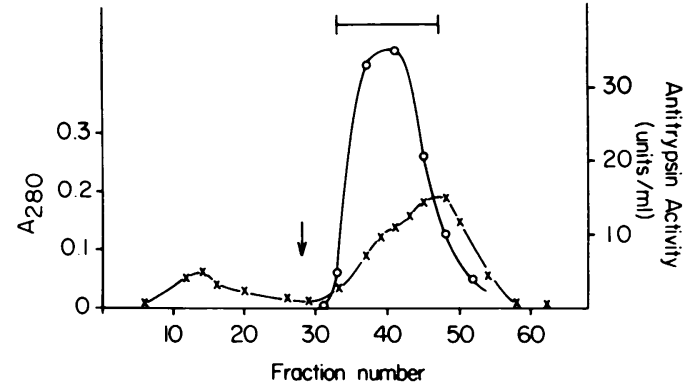

Figure 6 DEAE-cellulose chromatography. Fractions 108$122(|-|$, Fig. 5) from Sepharose-4B were pooled, concentrated and applied $(1.25 \mathrm{ml})$ onto a $1.5 \times 8-\mathrm{cm}$ column equilibrated with $0.005 \mathrm{M}$ phosphate buffer containing $0.05 \mathrm{M} \mathrm{NaCl}, \mathrm{pH} 6.5$. As indicated by the arrow a gradient consisting of $200 \mathrm{ml}$ of the above buffer in the mixing chamber and $200 \mathrm{ml}$ of the same buffer containing $0.2 \mathrm{NaCl}$ in the reservoir was started. 5-ml fractions were collected. Symbols are the same as Fig. 3 .

tein that represents $>90 \%$ of the total protein had a mobility similar to $\alpha_{1}$-protease inhibitor. To demonstrate that the major protein band represents the purified $\alpha_{1}$-protease inhibitor, crossed two-dimensional immunoelectrophoresis was performed. A duplicate unstained gel was placed in a $1 \%$ agarose containing $1 \%$ (vol/vol) $\alpha_{1}$-protease inhibitor antiserum immediately after disc gel electrophoresis and the proteins were subjected to electrophoresis into the second dimension. The rockets formed (Fig. 8) correspond to the region of the gels where the major protein bands migrated. In the normal ovary (Fig. 8A) the rocket was symmetrical, but in the ovarian carcinoma (Fig. 8B) a slower migrating shoulder appeared in front of the main rocket suggesting microheterogeneity. Analysis of the phenotype of the purified $\alpha_{1}$-protease inhibitor revealed a normal (PiMM) pattern for both normal and malignant ovaries. Both the normal and malignant ovaries show a major band on sodium dodecyl sulfate gel electrophoresis corresponding to a molecular weight of 53,500 (Fig. 9).

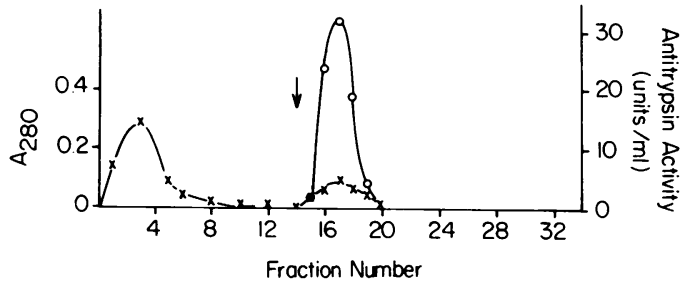

Figure 7 Con-A-Sepharose affinity chromatography. The preparation obtained from DEAE-cellulose ( $|-|$, Fig. 6) was pooled and concentrated and $3 \mathrm{ml}$ were applied onto a 1.5$\mathrm{ml}$ (packed volume) resin in a Pasteur pipette (See text). Elution of the $\alpha_{-1}$-protease inhibitor was initiated at the arrow with $0.1 \mathrm{M}$ solution of $\alpha$-methyl-D-glucoside in tris buffer (Methods). 1-ml fractions were collected with a flow rate of $7-\mathrm{ml} / \mathrm{h}$. Symbols are the same as Fig. 4. 
TABLE I

Purification of Ovarian $\alpha_{1}$-Protease Inhibitor

\begin{tabular}{|c|c|c|c|c|c|c|c|c|c|}
\hline & Protein & Volume & $\begin{array}{c}\text { Trypsin } \\
\text { inhibitory } \\
\text { activity }\end{array}$ & $\begin{array}{l}\text { Specific } \\
\text { activity }\end{array}$ & Purification & $\alpha_{1}$-PI & $\begin{array}{l}\text { Specific } \\
\text { activity }\end{array}$ & Purification & Yield \\
\hline & $m g / m l$ & $m l$ & $U / m l$ & U/mg & & $\mu g / m l$ & $\mu g / m g$ & & $\%$ \\
\hline \multicolumn{10}{|l|}{ From normal ovary } \\
\hline Soluble fraction & 1.335 & 45 & 130 & 97.4 & 1 & 40 & 30.0 & 1 & 100 \\
\hline QAE pool & 3.95 & 4 & 875 & 222 & 2.3 & 310 & 78.5 & 2.62 & 69 \\
\hline Sepharose-4B pool & 2.50 & 3 & 780 & 312 & 3.2 & 300 & 120 & 4 & 50 \\
\hline DE-52 & - & 7.2 & - & - & - & - & - & - & - \\
\hline Con-A Sepharose & 0.084 & 4.30 & 130 & $1,550.6$ & 16 & 76 & 905 & 30.2 & 18.2 \\
\hline \multicolumn{10}{|l|}{ From ovarian carcinoma } \\
\hline Soluble fraction & 1.65 & 25 & 66.5 & 40.3 & 1 & 30 & 18.2 & 1 & 100 \\
\hline QAE pool & 4.25 & 4.3 & 266 & 62.6 & 1.5 & 160 & 37.2 & 2.1 & 92 \\
\hline Sepharose-4B pool & 3.73 & 3.55 & 300 & 80.5 & 2 & 164 & 44.0 & 2.42 & 78 \\
\hline DE-52 & - & 6.66 & 一 & - & - & - & - & - & - \\
\hline Con-A Sepharose & 0.06 & 3.55 & 90 & 820 & 20.3 & 47.6 & 793 & 43.6 & 22.5 \\
\hline
\end{tabular}

All protein determinations were performed by micro Folin method, $\alpha_{1}$-protease inhibitor micrograms per milliliter was determined immunochemically as is the specific activity micrograms per milligram.

Kinetic studies. The inhibition of bovine trypsin by ovarian $\alpha_{1}$-protease inhibitor at various substrate $(\mathrm{Bz}$ Phe-Val-Arg- $p$ NA) concentrations is presented by the Lineweaver-Burk plot in Fig. 10. A competitive inhibi- tion of trypsin is observed by $\alpha_{1}$-protease inhibitor from normal ovary and ovarian carcinoma. Inhibition constant $\left(K_{\mathrm{i}}\right)$ values are calculated at 0.67 and $0.51 \mathrm{U}$, respectively.

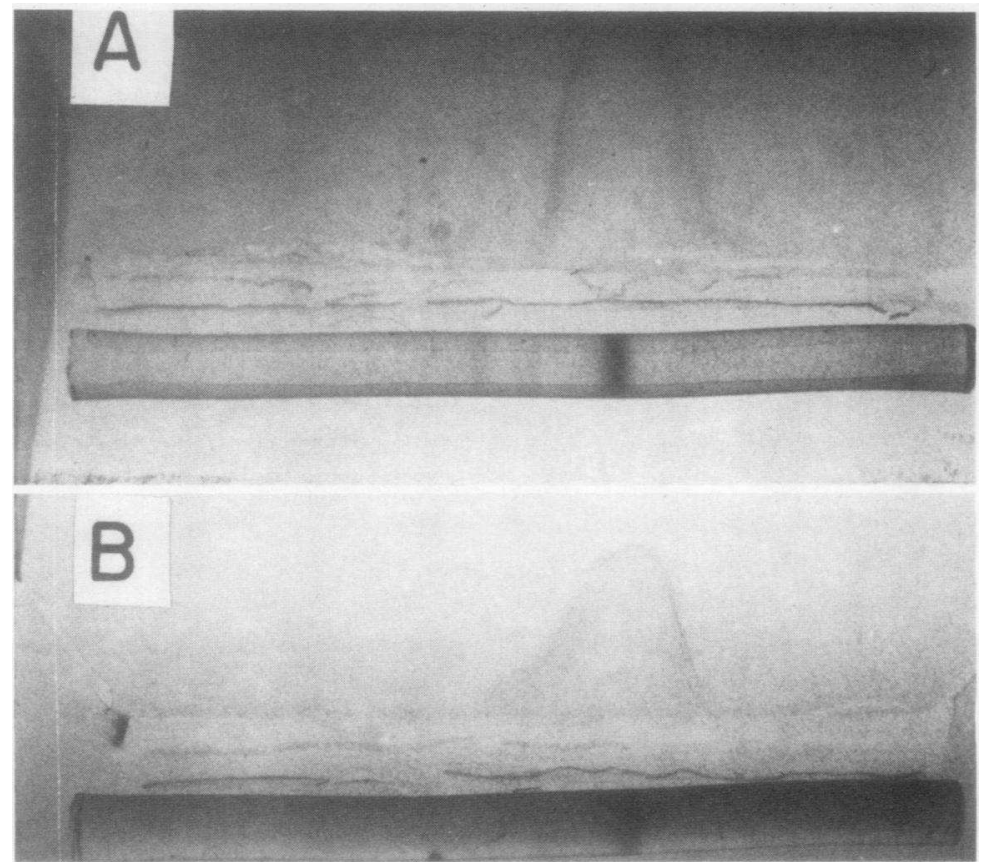

Figure 8 Crossed immunoelectrophoresis of purified $\alpha_{1}$-protease inhibitor. Tubes 15-20, Fig. 7 were pooled and concentrated. In the first dimension, $\alpha_{1}$-protease inhibitor obtained from concanavalin A-Sepharose step was applied onto alkaline disc gel (total protein used was $5 \mu \mathrm{g}$ for normal ovary (A) and $4.2 \mu \mathrm{g}$ for ovarian carcinoma (B). One gel was stained (presented in the figure). In the second dimension, a duplicate gel was electrophoresed into the antibody containing agarose gel (see text for detail). The plates were stained with Coomassie blue to visualize the immune precipitate (rocket). 


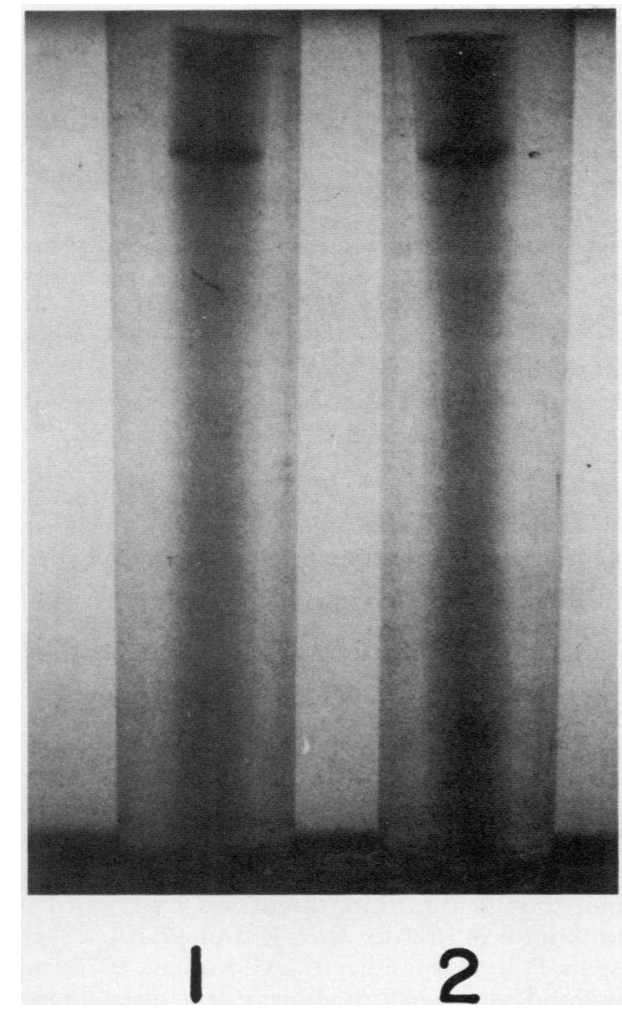

FIGURE 9 Sodium dodecyl sulfate gel electrophoresis of the highly purified $\alpha_{1}$-protease inhibitor. Preparations obtained from concanavalin A-Sepharose were used. The total proteins used were 5- $\mu \mathrm{g}$ for $\alpha_{1}$-protease inhibitor from normal ovary (gel 1) and $4 \mu \mathrm{g}$ for $\alpha_{1}$-protease inhibitor from ovarian carcinoma (gel 2).

\section{DISCUSSION}

$\alpha_{1}$-Protease inhibitor was identified immunohistochemically in epithelial, stromal and tumor cells of nine ovaries from nine patients by the use of specific anti$\alpha_{1}$-protease inhibitor antibody and the indirect peroxidase method. The interstitial space in the ovaries was essentially free of reaction product. Protease inhibitor from three ovaries was isolated, purified, and studied for its molecular, antigenic, and inhibitory activity.

Using the soluble fraction of the ovarian cell homogenates as a source of $\alpha_{1}$-protease inhibitor, purification by ion exchange chromatography, gel filtration, and lectin affinity chromatography resulted in a preparation that revealed a singel band on polyacrylamide disc gel electrophoresis in the presence and absence of sodium dodecyl sulfate. Crossed immunoelectrophoresis demonstrated that this protein band was identical to the $\alpha_{1}$-protease inhibitor antigen in plasma. Although $\alpha_{1}$ protease inhibitor from normal and malignant cells were similar in migration, a slower migrating shoulder was evident in the preparations of the $\alpha_{1}$-protease inhibitor from malignant tissue. The similarity to plasma

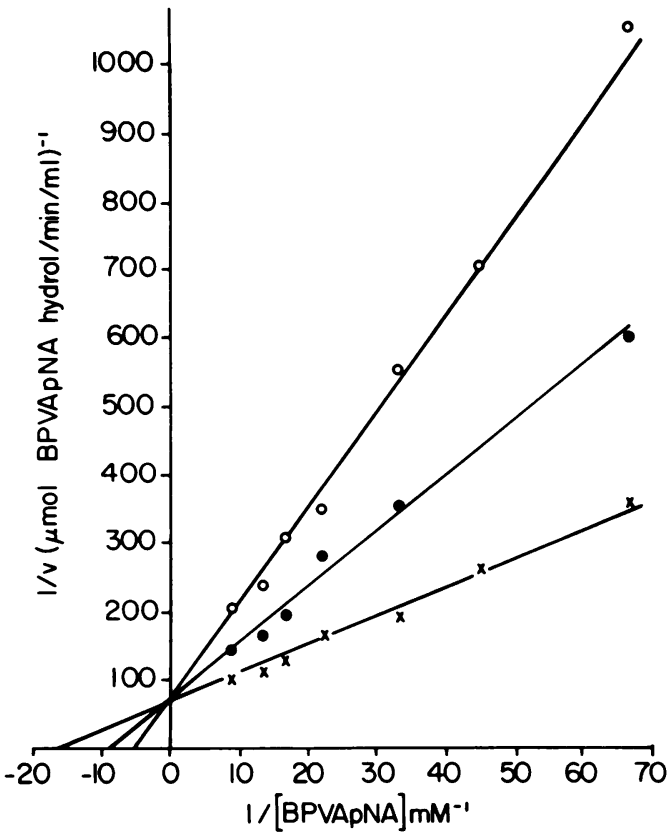

FIGURE 10 Kinetics of the inhibition of bovine trypsin by $\alpha_{1}$-protease inhibitor from ovarian tissue. In a total of $1 \mathrm{ml}$ vol, $0.25 \mu \mathrm{g}$ bovine trypsin was incubated with $0.1 \mathrm{M}$ Tris imidazole buffer at $\mathrm{pH} 7.4$ containing $0.1 \mathrm{M} \mathrm{NaCl}$ and $0.5 \mathrm{mg} / \mathrm{ml}$ bovine serum albumin $(X)$ or buffer plus $0.53 \mu \mathrm{g}$ $\alpha_{1}$-protease inhibitor from malignant ovary $(0)$ for 5 min at $30^{\circ}$. Bz-Phe-Val- $p$ NA at various concentrations was added and the residual amidase activity measured (Methods). The Con-A preparations of $\alpha_{1}$-protease inhibitor were used.

$\alpha_{1}$-protease inhibitor is further supported by the finding of a normal phenotype (PiMM). The molecular weight of normal and malignant ovarian $\alpha_{1}$-protease inhibitor as determined by gel filtration $(60,000)$ and sodium dodecyl sulfate-gel electrophoresis $(53,500)$ were in agreement with those reported for $\alpha_{1}$-protease inhibitor from plasma $(38,39)$ and platelets $(33)$.

Kinetics of trypsin inhibition by highly purified ovarian $\alpha_{1}$-protease inhibitor was competitive in nature similar to the inhibition of trypsin by platelet $\alpha_{1}$-protease inhibitor and renin by plasma $\alpha_{1}$-protease inhibitor (4).

This study clearly established that $\alpha_{1}$-protease activity is present in the cells of normal and malignant ovaries. However, the evidence presented does not distinguish between synthesis by ovarian tissue or endocytosis of $\alpha_{1}$-proteinase inhibitor by ovarian cells. The presence of $\alpha_{1}$-protease inhibitor in the stromal cells of ovaries may be important in ovulation since stromal cells as well as the epithelial (so-called germinal) cells participate in the maturation of follicles, production of estrogen and formation of the corpus luteum. Although the mechanism of rupture of the mature follicle is not fully understood, proteolytic enzymes may play a role. Plasminogen activator has been shown to be involved in ovula- 
tion (40). Other enzymes have been isolated from sea urchin eggs (41) including a homogenous enzyme similar to bovine trypsin in its molecular weight and susceptibility to inhibitors diisopropylfluro-phosphate and soybean trypsin inhibitor (42). The presence of the $\alpha_{1}$-protease inhibitor in ovarian tissue might serve to prevent extensive autodigestion of the tissue by tryptic enzymes following ovulation.

The number of samples examined in detail in this study was too small to allow comparison of the level of $\alpha_{1}$-protease inhibitor in normal and malignant ovarian cells. However, several studies suggest that inhibitor levels might be important, since increased protease activity is associated with transformation and uncontrolled proliferation (43-46). Cancerous tissues of the bladder contained significantly higher levels of the mammalian cellular protease inhibitors, urokinase inhibitor and tissue plasminogen activator inhibitor than normal mucosa (47). Ascitic fluid from patients with ovarian carcinoma contain much higher levels of trypsin inhibitors compared to ascitic fluid from patients with benign ovarian tumors (48). However, whether any of these inhibitory activities were due to $\alpha_{1}$-protease inhibitor is not known. $\alpha_{1}$-protease inhibitor has been demonstrated by immunoflorescence in sections of tumor tissue in patients with endodermal sinus tumors $(49,50)$, but a quantitative comparison with comparable normal tissue is not available. $\alpha_{1}$-protease inhibitor is also synthesized by a human hepatoma cell line (51). The presence of relatively high levels of $\alpha_{1}$-protease inhibitor in normal ovarian tissue and in malignant ovaries suggests that this inhibitor may be involved in the regulation of proliferation in normal and malignant tissues.

\section{ACKNOWLEDGMENTS}

The authors thank Dr. Richard Talamo of Johns Hopkins School of Medicine for performing the $\alpha_{1}$-protease inhibitor phenotyping and Mr. Charles Uschmann and Ms. Terry Cruice for preparation of the manuscript.

This project was partly supported by Specialized Center of Research grant HL14217 and research grant HL24365.

\section{REFERENCES}

1. Wu, F. C., and M. Laskowski. 1960. Crystalline acidlabile trypsin inhibitor from bovine blood plasma. J. Biol. Chem. 235: 1680-1685.

2. Turino, G. M., R. M. Senior, B. D. Garg, et al. 1969. Serum elastase inhibitor deficiency and $\alpha_{1}$-antitrypsin deficiency in patients with obstructive emphysema. Science (Wash. D. C.). 165: 709-711.

3. Eisen, A. Z., K. J. Bloch, and T. S. Sakai. 1970. Inhibition of human skin collagenase by human serum. J. Lab. Clin. Med. 75: 258-263.

4. Scharpe, S., M. Eid, W. Cooperman, and A. Lauwers. 1976. $\alpha_{1}$-Antitrypsin, an inhibitor of renin. Biochem. J. 153: 505-507.

5. Erickson, S. 1965. Studies in $\alpha_{1}$-antitrypsin deficiency. Acta Med. Scand. (Suppl. 177) 432: 1-85.
6. Lieberman, J. 1969. Heterozygous and homozygous

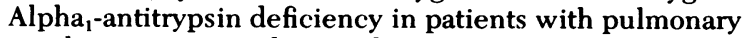
emphysema. N. Engl. J. Med. 281: 279-284.

7. Sharp, H. L., R. A. Bridges, W. Kruit, and F. Freier. 1969. Cirrhosis associated with alpha-1-antitrypsin deficiency: a previously unrecognized inherited disorder. J. Lab. Clin. Med. 73: 934-939.

8. Talamo, R. C., J. B. Blennerhassett, and K. F. Austen. 1966. Familial emphysema and alpha ${ }_{1}$-antitrypsin deficiency. N. Engl. J. Med. 275: 1301-1304.

9. Sharp, H. L. 1971. Alpha-1-antitrypsin deficiency. Hosp. Pract. 6 (5): 83-96.

10. Rowley, P. T., and L. L. Miller. 1975. Serum antitrypsin synthesis by the isolated perfused rat liver. Proc. Soc. Exp. Biol. Med. 148: 145-150.

11. Bhan, A. K., R. J. Grand, H. R. Colten, and C. A. Alper. 1976. Liver in $\alpha_{1}$-antitrypsin deficiency: morphologic observations and in vitro synthesis of $\alpha_{1}$-antitrypsin. Pediatr. Res. 10: 35-40.

12. Koj, A., E. Regoeczi, C. J. Toews, R. Leveille, and J. Gauldie. 1978. Synthesis of antithrombin III and alpha-1antitrypsin by the perfused rat liver. Biochim. Biophys. Acta. 539: 496-504.

13. Schnebil, H. B. 1974. Growth inhibition of tumor cells by protease inhibitors: consideration of the mechanism involved. Cold Spring Harbor Conf. Cell Proliferation. 1: 327-337.

14. Verloes, R., G. Atassi, P. Dumont, and L. Kananek. 1978. Tumor growth inhibition mediated by trypsin inhibitor or urokinase inhibitors. Eur. J. Cancer. 14: 23-31.

15. Moreau, P., J. Dornand, and J. G. Kaplan. 1975. Inhibition of lymphocyte transformation: effect of soybean trypsin inhibitor and synthetic anti-proteases. Can. J. Biochem. 53: $1337-1341$.

16. Schnebil, H. P., and M. M Burger. 1972. Selective inhibition of growth of transformed cells by protease inhibitors. Proc. Natl. Acad. Sci. U. S. A. 69: 3825-3827.

17. Bosmann, H. B. 1972. Elevated glycosidases and proteolytic enzymes in cells transformed in RNA tumor virus. Biochim. Biophys. Acta. 264: 339-343.

18. Beers, W. H., S. Strickland, and E. Reich. 1975. Ovarian plasminogen activator: relationship to ovulation and hormonal regulation. Cell. 6: 387-394.

19. Sternberger, L. A., P. A. Hardy, Jr., J. J. Cwiudis, and H. G. Meyer. 1970. The unlabeled antibody enzyme method of immunohistochemistry. Preparation and properties of soluble antigen-antibody (horseradish peroxidase-antihorseradish peroxidase) and its use in identification of spirockets. J. Histochem. Cytochem. 18: 315-333.

20. Pearse, A. G. E. 1972. Histochemistry: theoretical and applied. 3rd edition. Oxidoreductases I (Oxidases and Peroxidases). The Williams \& Williams Company, Baltimore 2: 850-857.

21. Ouchterlony, O. 1953. Antigen-antibody reactions in gels. IV. Types of reactions in coordinated systems of diffusion. Acta Pathol. Microbiol. Scand. 32: 230-240.

22. Deutsch, D. G., and E. T. Mertz. 1970. Purification from human plasma by affinity chromatography. Science (Wash. D. C.). 170: 1095-1096.

23. Colman, R. W., and A. Bagdasarian. 1976. Human kallikrein and prekallikrein. Methods Enzymol. 45: 303322.

24. Davis, B. J. 1964. Disc electrophoresis-II Method and application to human serum proteins. Ann. N. Y. Acad. Sci. 121: 404-427.

25. Weber, K., and M. Osborn. 1969. The reliability of molecular weight determinations by dodecyl sulfate-polyacrylamide gel electrophoresis.J. Biol. Chem. 244: 4406-4412. 
26. Murray, R. K., R. Suss, and H. C. Pitot. 1967. Isolation and Characterization of cytoplasmic components of cancer cells. Methods Cancer Res. 2: 239-286.

27. Swanti, P. L., S. Shibko, N. S. Kumata, and A. L. Tappel. 1964. Isolation of rat-liver lysosomes and their general properties. Biochim. Biophys. Acta. 85: 82-92.

28. Mancini, G., A. O. Carbonaro, and J. F. Heremans. 1965. Immunochemical quantitation of antigens by single radial immunodiffusion. Immunochemistry. 2: 235-254.

29. Scheidegger, J. J. 1955. Une micro-méthode de l'immunoélectrophorèse. Int. Arch. Allergy Appl. Immunol. 7: 103-110.

30. Laurell, C. B. 1965. Antigen-antibody crossed electrophoresis. Anal. Biochem. 10: 358-361.

31. Fagerhol, M. K., and C. B. Laurell. 1967. Polymorphism of "Prealbumins" and $\alpha_{1}$-antitrypsin in human sera. Clin. Chim. Acta. 16: 199-203.

32. Cuatrecasas, P. 1970. Protein purification by affinity chromatography. J. Biol. Chem. 245: 3059-3065.

33. Bagdasarian, A., and R. W. Colman. 1978. Subcellular localization and purification of platelet $\alpha_{1}$-antitrypsin. Blood. 51: 139-156.

34. Chase, T., and E. Shaw. 1967. p-Nitrophenyl-p-guanidinobenzoate HCL: a new active titrant for trypsin. Biochem. Biophys. Res. Commun. 29, 508-514.

35. Alkjaersig, N., A. P. Fletcher, and S. Sherry. 1959. EAminocaproic acid: an inhibitor of plasminogen activation. J. Biol. Chem. 234: 832-837.

36. Casati, P., M. Grandi, and N. Toccaceli. 1975. Urinary trypsin-inhibitor: extraction from pregnancy urine by affinity chromatography. Ital. J. Biochem (Engl. Ed.) 24: 188-198.

37. Pannell, R., D. Johnson, and J. Travis. 1974. Isolation and properties of human plasma $\alpha_{1}$-proteinase. Biochemistry. 13: $5439-5444$.

38. Crawford, I. P. 1973. Purification and properties of normal human $\alpha_{1}$-antitrypsin. Arch. Biochem. Biophys. 156: 215222.

39. Glaser, C. B., L. Karic, and R. Fallat. 1975. Isolation and characterization of alpha-1-antitrypsin from the Cohn Fraction IV-I of human plasma. Prep. Biochem. 5: 333-348.

40. Strickland, S. and W. H. Beers. 1976. Studies on the role of plasminogen activator in ovulation. J. Biol. Chem. 251: 5694-5702.

41. Carroll, E. J. 1976. Cortical granule proteases from sea urchin eggs. Methods Enzymol 45: 343-353.

42. Fodor, E. J., H. Ako, and K. A. Walsh. 1975. Isolation of a protease from sea urchin eggs before and after fertilization. Biochemistry. 14: 4923-4927.

43. Reich, E. 1975. Plasminogen activators: secretion by neoplastic cells and macrophages. In Protease and Biological Control. Cold Spring Harbor Conf. Cell Proliferation. 2: 333-341.

44. Roblin, R., C. Iih-Nan, and P. H. Blach. 1975. Proteolytic enzymes, cell surface changes, and viral transformation. Adv. Cancer Res. 22: 203-259.

45. Burger, M. D. 1970. Release from density dependent growth inhibition by proteolytic enzymes. Nature (Lond.). 227: 843-845.

46. Sefton, B. M., and H. Rubin. 1970. Release from density dependent growth inhibition by proteolytic enzymes. Nature (Lond.). 227: 843-845.

47. Hisazumi, H. 1973. Inhibitory effect of normal and cancerous tissues of the bladder on plasminogen activation. Invest. Urology. 11: 258-262.

48. Svandberg, L., and B. Astedt. 1975. Coagulative and fibrinolytic properties of ascitic fluid associated with ovarian tumors. Cancer (Phila.). 35: 1382-1387.

49. Palmer, P. E., H. Safaii, and J. J. Wolfe. 1976. Alpha ${ }^{-}$ antitrypsin and alpha-fetoprotein. Amer. J. Clin. Pathol. 65: 575-582.

50. Shirai, T., T. Itoh, and T. Yoshiki. 1976. Immunofluorescent demonstration of alpha-fetoprotein and other plasma proteins in yolk sac tumor. Cancer (Phila.). 38: 16611667.

51. Glasgow, J., A. Bagdasarian, and R. W. Colman. 1978. Alpha-1-antitrypsin produced by a human hepatoma cell line. Fed. Prod. 37: 1337. (Abstr.) 